\title{
A Study of Apology Strategies used by Bahdini Kurdish students with Reference to English
}

1Saeed A. Attieh, ${ }^{2}$ Ahmad R. Khalil

1,2 Department of English, College of Basic Education, University of Duhok, Kurdistan Region, Iraq

\begin{abstract}
This research studies the frequently used strategies by Kurdish students when they express their apology in their mother tongue. The present study tries to address two questions related as to whether the participants in questions follow the same strategies classified by Sugimotos (1997) or not, as well as the impact of gender factor on these strategies. The corpus consists of responses to Discourse Completion Test (DCT), which includes five different situations. The informants have been 30 subjects: 15 male students and 15 female students. The informants were students at college of basic education, English department, 4th stage. The DCT is written in English and informants were asked to write their responses in Kurdish. The data collected have been descriptively analyzed according to the content, frequency, and order of semantic formulas used by Sugimotos (1997). Finally, the most used strategies are translated into English also the Kurdish responses were written in English letters. In order to arrive at statistical results, the percentage of the most frequently used strategy was counted.
\end{abstract}

Keywords: apology, speech act, apology strategies, Bahdini apology, remorse.

\section{Introduction}

All People around the world do things with their words. For example, they order, promise, criticize and apologize and so on. In other words, to use language is to perform an action (Thomas, 2002:9).

Mere knowledge of language is not enough. For one to be able to communicate one's meaning functionally, one has to have both knowledge of the language and the social conventions that affect it (Sharifian 2005).

According to Van Dijk (1977: 155) users of any language always employ various speech acts to achieve their communicative goal. One of the main functions of language is the phatic communion. This function is related to the maintenance of social relations among

Academic Journal of Nawroz University

(AJNU) Volume 8, No 4 (2019).

Regular research paper: Published 30 Dec 2019

Corresponding author's e-mail : saed.a@gmail.com

Copyright @2018 1Saeed A. Attieh, 2Ahmad R. Khalil.

This is an open access article distributed under the Creative

Commons Attribution License. people. Thus, in the process of communication many factors related to the participants like assumptions and expectations about people, events, places... etc play an important role in the performance and interpretation of linguistics expressions (Nureddeen, 2008: 279).

Apology can be regarded as a part of human communication to maintain good relations between people or to restore harmony. Thus, we can say that people in different cultures all over the world use different apology strategies when they apologize to each other in different situations.

\section{What is Apology?}

Generally, apologies fall under expressive speech acts, where the speaker tries to indicate his own state or attitude. Goffman (1971) views apologies as "remedial interchanges serving to re-establish social harmony after a real or virtual offence or in Olshtain and Cohen terms whether the offence is real or potential" (1983, p. 20). 
Apology is a communicative act in the production of which an apologiser has to act politely, both in the vernacular sense and in the more technical sense of paying attention to the addressee's face wants (Brown and Levinson, 1987:70).

Apology is defined as" a speech act which is intended to provide support for the hearer who was actually or potentially mal affected by a violation (Olshtain, 1989: 156).

According to Holmes (1990:155), apologies are defined as "primarily social acts, carrying effective meaning". He believes they are politeness strategies meant to remedy an offense on the part of the speaker. Gooder and

Jacob (2000: 272) point out that the proper apology acknowledges the fact of wrong deed, accepts ultimate responsibility, expresses sincere regret and sorrow and promises not to repeat the offense.

For Edmondson (1981: 144), an apology is triggered as follows (key: $\mathrm{S}=$ speaker; $\mathrm{H}=$ hearer):

$\mathrm{S}$ wishes $\mathrm{H}$ to believe that $\mathrm{S}$ is not in favor of an act (A) performed by $\mathrm{S}$ as against the interests of $\mathrm{H}$.

In 'apologize', S may be held to regret that he $\operatorname{did} \mathrm{A}$, and to discredit himself socially for having done so.

Deutschmann (2003: 44-47) states that any apology includes the following components:

- An "offender", who takes responsibility for some offence or who feels

- directly or indirectly responsible for something,

- An "offended", who is affected, potentially affected or just perceived to be affected by the offence,

- An "offence", which may be real, potential or only perceived as an offence, and

- A "remedy", which is "a recognition of the offence, acceptance of responsibility and a display of regret."

\section{Apology as a Speech Act}

As a type of speech act, apology has also been the object of numerous studies such as (Al-Hami, 1993; Bataineh \& Bataineh, 2006; Alfattah, 2010; Banikalef \& Marlyna, 2013; Ugla \& Zainol Abidin, 2016; etc.). These studies attempted to clarify what exactly an apology is, how the different ways of apologizing can be classified, and how this particular speech act is performed and perceived both in English and in different languages around the world.

The act of apologizing is called for when there is some behavior which has violated social norms. When an action or an utterance has resulted in the fact that one or more persons perceive themselves as offended, the culpable person(s) need(s) to apologize. We are dealing here, therefore, with two parties: an apologizer and an apologizee. However, only if the person who caused the infraction perceives himself or herself as an apologizer do we get the act of apologizing. The act of apologizing requires an action or an utterance which is intended to "set things right" (Olshtain, 1983:235).

Olshtain (1989:156-7) defines an apology as "a speech act which is intended to provide support for the hearer who was actually or potentially mal-affected by a violation." When speakers agree to offer an apology, they are willing to humiliate themselves to an extent which, by definition, makes an apology a face-saving act for the hearer and a face-threatening act for the speaker, in Brown and Levinson's (1978) terms.

For Holmes (1990:156), apology is a speech act addressed to remedy an offence for which the apologizer takes responsibility, and thus to restore equilibrium between the apologizer and the person offended. We can understand that what a person does when he utters an apology statement is that he is willing to humble himself or herself and to concede the mistake and responsibility as an attempt to restore a harmonious relationship with the interlocutor. 
Bergman and Kasper (1993) define an apology as a "compensatory action to an offense in the doing of which S was casually involved and which is costly to $\mathrm{H}^{\prime \prime}$ (p. 82). By 'costly' is meant that it is face-threatening or there will even be a severe misunderstanding. Direct apology is represented by expressions like 'I apologize' and 'I'm sorry'. But there are other indirect apology strategies that represent a mild apology for simple routine offensive actions like sneezing, coughing, interrupting, etc. The offender uses other expressions and verbs like regret, forgive, pardon, justification/explanation, etc.

According to Bataineh \& Bataineh (2006:1903), apologies fall under expressive speech acts in which speakers attempt to indicate their state or attitude. They add that in order for an apology to have an effect, it should reflect true feelings.

To sum up, it worth mentioning that apology is a speech act which can be regarded as a reaction to a behavior which violated the social norms. Therefore, the culpable person who caused the offense needs to apologize.

\section{Types of Apologies}

Bergman and Kasper (1993) distinguished the following seven different categories of apology.

- The Illocutionary Force Indicating Device (IFID) such as in example (1) below.

\section{(1) I'm sorry.}

- $\quad$ The intensified IFID as in example (2).

(2) I'm terribly sorry.

- Taking responsibility as in example (3).

(3) I haven't graded it yet.

- Giving an account of the reasons that led to the action that requires an apology as in example (4).

(4) I was suddenly called to a meeting.

- Minimizing the effects and severity of the action as in example (5).
(5) I'm only 10 minutes late.

- offering repair or compensation as in example (6).

(6) I'll pay for the damage.

- $\quad$ verbal redress as in example (7).

(7) It won't happen again.

The last one seems to be very close to the minimization category, if we take into account the example used by the authors, "I hope you didn't wait long" (Bergman \& Kasper, 1993: 86).

\section{Apology Strategies}

According to Olshtain and Cohen (1983) if the offender accepts the responsibility for the offense committed, $\mathrm{s} /$ he may select five possible strategies to apologize, which are as follows:

- An expression of apology

A. An expression of regret, e.g., I'm sorry (mote?asefam)

B. An offer of apology, e.g., I apologize (?ozr/ma?zerat mixa^m)

C. A request for forgiveness, e.g., forgive me (bebaxs`id)

- An explanation or account of the situation, e.g., The bus was late (?otobus dir kard).

- An acknowledgement of responsibility

A. Accepting the blame, e.g., It was my fault (taqsire man bud).

B. Expressing self-deficiency, e.g., I was confused (man gij budam).

C. Recognizing the other person as deserving apology, e.g., you are right (haq ba^ šoma^st).

D. Expressing lack of intent, e.g., I didn't mean to (manzuri nada^štam).

- An offer of repair, e.g., I'll help you get up (komaket mikonam boland s`i).

- A promise of forbearance, e.g., It won't happen again (dige tekra^r nemis`e). 


\section{The Model Adopted}

The model adopted in this study is that by Sugimoto (1997). Sugimoto divides apology strategies into primary strategies, secondary strategies, and seldom used strategies. For each of these types, there are subtypes as well. The apology strategies that are used by the respondents who participated in this study have been identified and then classified based on Sugimoto's (1997) strategies. The strategies that are used by the participants have been tabulated in order to identify the apology strategies they used. The tabulation of the results made it possible to determine the strategies that are used and whether or not Sugimoto's (1997) results apply to Kurdish respondents. It further helped to clarify whether or not gender has an effect since previous research had reported that females apologize more than males (Brown, 2001; Holmes, 1995).

\section{Data Analysis}

Sugimoto's (1997) strategies have been used as the basis of the analysis. Statement of remorse was the strategy most frequently used by male and female respondents across the sample. Unlike Sugimoto, the different manifestations of this strategy have been tabulated in terms of the use of expressions of apology and the various numbers of intensifiers. In order to identify the apology strategies used, the study provides tables to clarify the method used to show remorse (the overt expression of apology), and to show the other apology strategies employed in each situation and their percentages. All the apology strategies used by the respondents have been listed. The five situations given to students to apologize have been analyzed and as follows:

\subsection{Situation (1)}

Table (1) bellow shows how males and females used apology strategies when apologizing for an offend in situation one. Nearly all sorts of strategies given by
Sugimoto (1997) were used in situation one by Kurdish speakers. However, the mostly employed strategies were the primary ones with their sub divisions. As shown in the above table, 13 females out of 15 used the primary remorse strategy whereas the other remaining two used different strategies and interestingly one of them is also the primary remorse but it is mixed with the account strategy. On the other hand, males also used primary remorse strategies with account ones and more than half of them preferred this mixture. In other words, 8 out of 15 males did so. Three males also, similar to females, used purely primary remorse strategies. Another male used a remorse with selfcastigation whereas the other used different strategies.

Table (1): Frequencies of apology strategies used by males and females for situation one

\begin{tabular}{|l|l|l|}
\hline Strategy & Male & Female \\
\hline Primary Remorse & 3 & 13 \\
\hline $\begin{array}{l}\text { Primary Remorse + } \\
\text { account }\end{array}$ & 8 & 0 \\
\hline Remorse + self & 1 & 1 \\
\hline Seldom - gratitude & 2 & 1 \\
\hline $\begin{array}{l}\text { Secondary } \\
\text { compensation }\end{array}$ & 1 & 0 \\
\hline
\end{tabular}

Here are some examples of the primary remorse strategies used by females with their renderings:

$$
\text { داخازا ليبورينى دكةم بخودى يا بـ دةقتى من بوو. }
$$

Dakhaza liborini dakam bkhude ya bi dasti mn bu.

I would like you to accept my apology. I swear it was out of my control.

$$
\text { هيثى دكم ببوره من هازي نهبوو خيشك من يا بيحيك دراند. }
$$

Hevi dakam bbora mn hazhi nabu kheshka mn ya bchik drand.

Please accept my apology. I didn't know. My little 
sister tore it.

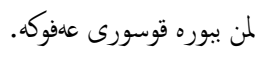

L mn bbora qusure aafoka

Accept my apology. So sorry.

Some examples of males' use of primary strategies are given below:

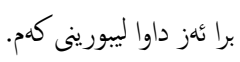

Bra az dawa li borini kam.

Brother, I hope you accept my apology.

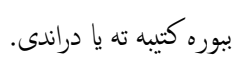

Bbora kteba ta ya drande

Sorry, your book is tore.

$$
\text { ل ل من ببوره براى من يا يخوك دمفتهرا ته قةثاند. }
$$

L mn bbora brai mn ya bchuk daftra ta qatand.

Sorry, my little brother tore your book.

Kurdish language, like all other languages, has certain ways of apology. Kurdish speakers often regret wrong actions by using certain words such as بورة"bbore "(sorry) and قوسيرى عهوكه "qusere aafo ka" (forgive me) and the like. The use of such words and expressions conveys verbal messages that invoke the real intention of the speaker to apologize for wrong actions. Politeness strategy in English introduced by Brown and Levinson (1987) is also available in Kurdish language. However, and in the light of the participants' responses, the degree of indirectness is not in the same level in general as is found in English language. Nevertheless, Kurdish females used a more polite and somehow less direct way to apologize than male participants.

\subsection{Situation (2)}

Two main types of Sugimoto (1997) strategies were used by participants in situation two as shown in Table (2) below. They are the primary and seldom used strategies. However, the former was used highly than the latter. Primary remorse with an account strategy ranked number one when 13 males preferred to employ them in their apologies. One other male used a purely primary remorse strategy and the other used a seldomself strategy. On the contrary, 11 female participants used the purely primary remorse strategy, two used seldom-explicit, one seldom-self and one the seldomcontext strategy.

Table (2): Frequencies of apology strategies used by males and females for situation two

\begin{tabular}{|l|l|l|}
\hline Strategy & Male & Female \\
\hline Primary Remorse & 1 & 11 \\
\hline $\begin{array}{l}\text { Primary Remorse + } \\
\text { account }\end{array}$ & 13 & 0 \\
\hline $\begin{array}{l}\text { Seldom + self- } \\
\text { castigation }\end{array}$ & 1 & 1 \\
\hline $\begin{array}{l}\text { Seldom - explicit } \\
\text { Seldom - } \\
\text { contextualization }\end{array}$ & 0 & 2 \\
\hline
\end{tabular}

In what follows, some examples of how these strategies are used will be given:

- Primary remorse with account strategies as used by male participants:

$$
\text { ببوره برائهز كهلك كير بوو. }
$$

Bbora bra az galag gir bum.

Sorry brother. I was so late.

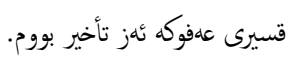

Qsira aafo ka az taakhir bum.

Forgive me. I was late.

$$
\text { داخازا ليبورينى دككم. بو من موشكيله جيبو. }
$$

Dakhaza liborini dakam. Bu mn mushkila chebo.

I would like you to accept my apology. I had a problem.

- Seldom-self strategy as used by a male participant: 
من مهجال نهبو بيسي.

Mn majal nabu bem.

I had no time to come.

- Primary remorse strategies as used by female participants:

$$
\text { تو بخودى لمن ببوره. باوهر بكه من كارهك تهيبو. }
$$

Tu bkhudi lmn bbora. Bawer bka mn karek chebo.

For God sake accept my apology. Believe me I had some work to do.

$$
\text { كةردنه من ئزا بكه كو ئهز درنك كههشت. }
$$

Gardna mn aza bka ko az dreng gahashtm.

Forgive me for arriving late.

$$
\text { تو بخودى قوسيرى من عهفو كه نهب دمستين من بوو. }
$$

Tu bkhudi qusiri mn aafo ka na b dastin mn bu.

For God sake forgive me. It was not in my hands.

- Seldom-expilicit strategies as used by female participants:

$$
\text { باوور بكه دا زى هيم بله زروفى من وملى هاتن. }
$$

Bawer bka da zi hem bas zroofi mn wali hatn.

Believe me I wanted to come but I had some circumstances.

Male participants apologized normally in their mother language whether using primary or seldom strategies. However, the cultural context is reflected very clearly in females' apologies. The use of تو بخدى "tu bkhudi" (for God sake) which is repeated more than once depicts the Kurdish Islamic culture. The aim of using this word is to apologize more tactfully and softly. Moreover, Kurdish culture is extremely reflected in the use of the phrase كهردنه من ثازا بكه "gardna mn aza bka" (forgive me). It can be deduced that Kurdish females worry more about wrong actions than their male counterparts. This is reflected obviously in their use of two cultural traits phrases as appears in situation two.

\subsection{Situation (3)}

Table (3) below shows that primary strategies once more were used more than others in this situation. Similar to the previous situation, 13 male participants mixed remorse with account primary strategies for their apologies. The remaining two males used seldomself strategies. Whereas 8 females used purely remorse strategies, 6 used seldom-self and one used seldomexplicit.

Table (3): Frequencies of apology strategies used by males and females for situation three

\begin{tabular}{|l|l|l|}
\hline Strategy & Male & Female \\
\hline Primary Remorse + account & 13 & 0 \\
\hline Primary Remorse & 0 & 8 \\
\hline Seldom + self-castigation & 2 & 6 \\
\hline Seldom - explicit & 0 & 1 \\
\hline
\end{tabular}

Some examples of the use of these strategies will be given here and as follows:

- Primary remorse with account strategies as used by male participants:

$$
\text { من ببوره ئهز نه خوش بووم ئهز نه شيام. }
$$

Mn bbora. Az na khosh bum az na shyam.

Sorry. I was sick. I couldn't.

$$
\text { بوره سيدا ئهز كهلك نه خوش بووم. }
$$

Bbora saida. Az galag na khosh bum.

Sorry sir. I was so sick.

- Seldom-self strategies as used by male participants:

$$
\text { نه شيام لهوا نه يى ب حازربه. ببوره بروفيسور. }
$$

Na shyam lawa nay a $b$ hazr bm. Bbora professor.

I couldn't prepare it. Sorry professor.

- Primary remorse strategies as used by female participants:

$$
\text { بوره بيجحك ئهز يا نهساخ بووم. }
$$

Bbora pichak az ya nasaq bum.

Sorry. I was a little sick. 


$$
\text { بوره من نهشيام ئنز يا نهساخ بووم. }
$$

Bbora mn na shyam az ya nasaq bum.

Sorry. I couldn't. I was sick.

- Seldom-self castigation strategies as used by female participants:

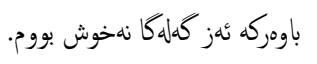

Bawer ka az galaga na khosh bum.

Believe me I was very sick.

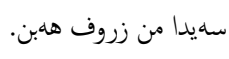

Saida mn zroof haben.

Sir! I had special circumstances.

In this situation, because there is a difference in status between the offender and the offended, Kurdish speakers apologized politely using a primary strategy mostly. Moreover, and culturally speaking, Kurdish people respect teachers and avoid offending them. This is clearly reflected in the use of the word "saida" (sir). Therefore, when an offence takes place, they regret it using a suitable apology strategy. It is found also that approximately half of the female participants used a seldom strategy. It is believed that females used such a style in order to add more effectiveness to their apology. They wanted to make their excuses stronger. Therefore, females again showed that their style is soft and more tactful.

\subsection{Situation (4)}

Table (4) below shows that 13 male participants used remorse with account primary strategies in this situation. One used remorse with compensation primary strategy and another male used a seldom-self strategy. On the other hand, females, unlike the previous situation, 7 females out of 15 used the same of males' strategy in apologizing, i.e. primary remorse with account strategy. Other 7 females used seldomcontextualization strategy and one used remorsedescription strategy.
Table (4): Frequencies of apology strategies used by males and females for situation four

\begin{tabular}{|l|c|c|}
\hline Strategy & Male & Female \\
\hline Primary Remorse + account & 13 & 7 \\
\hline Primary Remorse + description & 0 & 1 \\
\hline $\begin{array}{l}\text { Primary Remorse + } \\
\text { compensation }\end{array}$ & 1 & 0 \\
\hline Seldom - self & 1 & 0 \\
\hline Seldom -context & 0 & 7 \\
\hline
\end{tabular}

Some examples of these strategies will be given here and as follows:

- Primary remorse with account strategies as used by male participants:

$$
\text { سهيدا من ببوره. باوهر بكه ئهز كير بووم بهر ترافيك لايتى. }
$$

Saida zh mn bbora. Bawer bka az gir bum ber traffic layete.

Sorry sir. Believe me I was late because of traffic lights.

$$
\text { بوره سهيدا ل ترافيكى كهلك ئيزيحام بوو لهوا ئنز كير بووم. }
$$

Bbora saida l trafike galag ezdihaam bu lawa az gir bum.

Sorry sir. There was a crowd in the traffics that is why I was late.

- Seldom-self castigation strategy as used by one male participant:

$$
\text { ئهز دمرنك كههشتم بهريز رثبهر خهبسه. }
$$

Az dreng gahashtm barez zhbar khabsa.

- Primary remorse with account strategies as used by female participants:

$$
\text { ردل داخازا لييورينى دكمم بو كير بوونى بهس نه بدهستى من بوو. }
$$

Zh dl dakhaza liborini dakam bu gir bui bas na b dasti mn $b u$.

From heart I wish you accept my apology for being late but it was out of my hand.

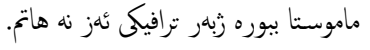

Mamosta bbora zhbar trafiki az na hatm.

Sorry teacher. I didn't come because of traffics.

- Seldom-contextualizationstrategiesas used by 
female participants:

$$
\text { سهيدا هاتو جوويا كوردستانى زور ب زمحمته. }
$$

Saida hatu chuya kurdstane zoor b zahmata.

Sir! Kurdistan traffics are difficult.

$$
\text { باونر كه شارع خهبسه بوون. }
$$

Bawer ka sharia galag khabsa bun.

Believe me the street was so crowded.

The same respect and politeness shown in the previous situation is also shown in this situation. It is obvious that the 13 males who expressed regret by using the word بوره "bbora" (sorry) with a report of what happened used somehow longer words because they tended to show more respect to their teacher. Also the use of words such as "saida" (sir) and "mamosta" (teacher) indicates more politeness and respect. 7 females followed them in this way which is comparatively different from situation (3) in which no female did so. 7 other females used a seldom- strategy again to reinforce the power of regret and apology.

\subsection{Situation (5)}

The case in situation (5) is similar, as is shown in table (5) below, to situation (3) and situation (4) in that 13 males out of 15 used primary remorse with account strategy to express regret over an offence. One used primary remorse mixed with secondary strategy and the other used seldom-self strategy. On the other hand, 10 females used a purely primary remorse strategy without mixing it with other strategies, 3 females used seldom-context strategy.

Table (5): Frequencies of apology strategies used by males and females for situation five

\begin{tabular}{|l|c|c|}
\hline Strategy & Male & Female \\
\hline Primary Remorse + account & 13 & 0 \\
\hline Primary Remorse only & 0 & 10 \\
\hline Primary Remorse +secondary & 1 & 0 \\
\hline
\end{tabular}

\begin{tabular}{|l|c|c|}
\hline Seldom - self & 1 & 3 \\
\hline Seldom -context & 0 & 2 \\
\hline
\end{tabular}

In what follows, some examples of how those strategies are used will be given:

- Primary remorse with account strategies as used by male participants:

$$
\text { داوا ليبورينى زثنه دككم ثئز نه هاتم بو داوا ته ته. }
$$

Dawa liborini zh ta dakam az na hatm bo dawata ta.

I wish you accept my apology. I didn't come to your invitation.

$$
\text { ببوره ثنز نه شيام بيهم جنكى من كلهك محازره هلبون. }
$$

Bbora az na shyam behim chnki mn galag mahazara habun.

Sorry I couldn't come because I had many lectures.

- Seldom-self strategies as used by male participants:

$$
\text { من كهله محازره هبون لهوا ئنز نه شيام بهيم. }
$$

Mn galag mahazara habun lawa az na shyam behim.

I had many lectures that is why I couldn't come.

- Primary remorse strategies as used by female participants:

$$
\text { زدل داخازا ليبورينى دككم ئهز نه شيام زانكويا بهيلم رّبهر من كلهلك واجب ههبون. }
$$

Zhdl dakhaza liborini dakam az na shyam zankoya behelm zhbar mn galag wajb habun.

From hear I would like you to accept my apology. I couldn't leave university because I had lots of assignments.

$$
\text { بوره ئهز نه شيام بهيم ربّهر ئهزمونا زانكويا. }
$$

Bbora az na shyam behim zhbar azmona zankoya.

Sorry I couldn't come due to university exams.

- Seldom-self strategies as used by female participants:

$$
\text { باومر كه كنز نه شيام بهيم حنكو من كاركا هلبو. }
$$

Bawer ka az na shyam behim chnko mn karaka habu.

Believe me I couldn't come because of I had a work to do.

13 out of 15 males who apologized for their teacher in 
situation (3) and situation (4) apologized to their friend in situation (5). The difference is in the use of the words "سميد "maida" (sir) and "مarasta" (teacher) in the previous situations. On the other hand, the factor of social status is reflected in females' responses. females used not only primary strategies but also seldom strategies. The purpose of using such strategies is to be more polite with interlocutors with higher status. The number of these strategies is comparatively more than those with equal status.

\section{Conclusions}

It can be concluded that Kurdish speakers use their own way that is found in their culture to apologize. There are certain Kurdish expressions used to trigger apology such as بورة "bsere aafo ka" which stand for the English words (sorry) and (forgive me) respectively. It is found also that cultural and religious implications are reflected obviously in Kurdish speakers' apologies through the use of the expression " كهدرده من ئزا بكه "grdna mn aza bka" (forgive me) and تو تو "tu b khudi" (for God sake). The former has a special Kurdish identity when someone does a wrong action and tells the offended to clear-self him for what happened. Whereas the latter has, in addition to its Kurdish nature, an Islamic implication when, after an offence takes place, you ask s/he for the God sake to accept the apology. A further conclusion that can be drawn upon is that Kurdish females used longer strategies than males did. The purpose behind that is to use a tactful language and style to make the apology more polite. Moreover, females used seldom strategies to make their apology more influential. They used it to be less direct and consequently more polite. It can also be noticed that in the way of apologizing when the offended part is higher in status, Kurdish speakers used mitigation words such as سميد "saida" (sir) and "mamosta" (teacher) to show respect and politeness to the offended party. Finally, it can be concluded that Kurdish speakers in general used a polite way to apologize according to their mother language which comparatively not as polite as English speakers do. This can be recognized clearly from the degree of indirectness used and the relative length of the strategies employed.

To sum up, all the strategies listed by Sugimoto's (1997) are used by Kurdish speakers in the present study. This indicates that Kurdish speakers are not very different from English speakers in the use of apology strategies.

\section{References}

1. Al- Hami, F. (1993). Forms of Apology Used by Jordanian Speakers of EFL: A Cross- Cultural Study. Unpublished Master's Thesis, University of Jordan.

2. Alfattah, M. (2010). Apology Strategies of Yemeni EFL University Students. MJAL 2(3). 223-249.

3. Banikalef, A. \& Marlyna., M (2013). Social beliefs for the realization of the speech acts of apology among Jordanian EFL graduate students. English Linguistic Research, 2(1). Pp. 134-145.

4. Bataineh, R. F. \& Bataineh, R. F. (2006). Apology strategies of Jordanian EFL university students. Journal of Pragmatics, 38, 1901-1927.

5. Bataineh, R.F and Bataineh, R.F. (2006). Apology Strategies of Jordanian EFL university students. Journal of Pragmatics 38(11). 1901-1927.

6. Bergman, M. L., \& Kasper, G. (1993). Perception and performance in native and nonnative apology. In G. Kasper \& S. Blum-Kulka (Eds.), Interlanguage pragmatics (pp. 82-107). New York: Oxford University Press.

7. Brown, P., \& Levinson, S. (1978). Universals in language usage: politeness phenomena. In E. Goody (Ed.), Questions and Politeness (pp. 56-311). Cambridge: Cambridge University press.

8. Deutschmann, M. 2003. Apologizing in British English. Unpublished Doctoral Dissertation, Umeå University.

9. Edmondson, W. (1981). Spoken Discourse: A Model for Analysis. 
10. Goffman, E. (1971) Relations in public. Harmondsworth: Penguin.

Gooder, H. and Jacob, J. M. (2000). '"On the Borders of the Unsayable": the apology in postcolonizing Australia'. Interventions. International Journal of Postcolonial Studies (August): 230-48.

11. Holmes, J. (1990). Apologies in New Zealand English, Language in Society 155-199. Cambridge University Press.

12. Holtgraves, T. ( 2002) .Language As Social Action : Social Psychology And Language Use. Lawrence Erlbaum Associates, Publishers. London

13. London: Longman.

14. Nureddeen, F.A. (2008). “Cross Cultural Pragmatics: Apology Strategies in Sudanese Arabic". Journal of pragmatics, 40, pp: 279 -306.

15. Olshtain, E. (1983). Sociocultural competence and language transfer: the case of apology. In Gass, Susan M., \& Selinker, Larry (Eds), Language Transfer Language Learning. Newbury House, Rowley, MA. pp. 232-249

16. Olshtain, E. (1989). Apologies across languages. In S. Blum-Kulka, J. House \& G. Kasper (Eds.), Crosscultural pragmatics: Requests and apologies (pp. 155174). Norwood, NJ: Ablex Publishing Corporation.

17. Olshtain, E. and Cohen, A. D. (1983). Speech act behavior across languages. In $\mathrm{H}$. W. Dechert et al. (Eds.), Transfer in production (pp. 53-67). Norwood, NJ: Abl.

18. Sharifian, F. (2005). The Persian cultural schema of shekasteh-nafsi: A study of compliment responses in Persian and Anglo-Australian speakers. Pragmatics and Cognition 13.2: 337-361.

19. Sugimoto, N. (1997). 'A Japan- U. S. comparison of apology styles'. Communication Research (24), pp: 349 370.

20. Ugla., R., L. \& Zainol Abidin., M., J. (2016). A Study of Apology Strategies Used by Iraqi EFL University Students. International Journal of Evaluation and Research in Education(IJERE) 5(1), pp. 32-38.

21. Van Dijk, T. A. (1977) .Text and Context. London: Longman.

\section{Appendix}

DCT

\section{SITUATION 1:}

At the professor's office you have borrowed a book from your teacher, which you promised to return today.

When meeting your teacher, however, you realize that you forgot to bring it along.

Teacher: "I hope you brought the book I lent you."

You apology saying :

Teacher: "OK, but please remember it next week."

\section{SITUATION 2:}

You promised you would buy your neighbor a newspaper while in town, but you forgot.

Your neighbor: "Did you get the paper?"

You apology saying:

\section{SITUATION 3:}

An acquaintance you had given bus directions to the day before sees you on the street.

The acquaintance: "You know you gave me the wrong bus number for the movie theatre yesterday! By the time we got there, we had already missed half the movie."

You apology saying:

\section{SITUATION 4:}

Parking your car at work in the morning, you bump into a colleague's car. The other car is damaged and it is clearly your fault. Your colleague is there.

You apology saying:

Your colleague: Do not worry.

SITUATION 5:

You arranged to meet a friend in order to study together for an exam. You arrive half an hour late for the meeting.

Friend: "I have been waiting at least half an hour for you!"

You apology saying: 